\title{
Penggunaan Media Sosial Sebagai Alat Komunikasi Politik
}

\author{
Sukma Alam \\ sukma.alam@budiluhur.ac.id \\ Universitas Budi Luhur, Jl. Ciledug Raya No.99, Jakarta, Indonesia
}

Submitted: 23 Maret 2021, Revised: 21 April 2021, Accepted : 24 Mei 2021

\begin{abstract}
Abstrak
Berkembanganya teknologi komunikasi yang semakin canggih menjadi tantangan bagi partai politik dan aktor politik dalam berkomunikasi. Media sosial menawarkan informasi yang tidak hanya cepat tetapi efisien dan segementasi yang tepat. Kemampuan media sosial mempunyai kekuatan dalam memengaruhi opini publik bahkan penggalangan dukungan. Oleh karena itu, partai politik atau aktor politik harus mampu mengelola media sosial dan menjadikan media sosial sebagai ruang komunikasi untuk mengoptimalkan komunikasi di berbagai sektor. Penelitian ini bertujuan untuk mengetahui penggunaan media sosial sebagai alat komunikasi politik yang dilakukan Dewan Pimpinan Wilayah Partai Soldaritas Indonesia (DPW PSI) Jakarta. Metode penelitian menggunakan pendekatan kualitatif dan metode studi kasus. Pengumpulan data dilakukan melalui observasi online pada akun media sosial Instagram, Twitter, dan Facebook DPW PSI Jakarta dan wawancara dengan admin media sosial DPW PSI Jakarta dan Ketua DPW PSI Jakarta melalui Google Meet. Hasil penelitian ini menunjukan bahwa menggunakan media sosial mampu memberikan dampak pengaruh ke publik dengan mengunggah konten berupa video, foto dan infografis serta caption menarik, sehingga publik akan merespons konten tersebut (feedback). Selain itu, media sosial juga sangat membantu dalam proses komunikasi politik seperti menyerap aspirasi publik, komunikasi dua arah dan pesan yang disampaikan lebih jelas dan efektif.
\end{abstract}

Kata kunci: media sosial, komunikasi politik, partai politik

\section{The Use Of Social Media as Political Communication Tool}

\begin{abstract}
The development of increasingly sophisticated communication technology is a challenge for political parties and politician in communicating. Social media offers not only fast but efficient information and precise segmentation. The ability of social media has the power to influence public opinion and even raise support. Therefore, political parties or politician must be able to manage social media and make social media a communication space to optimize communication in various sectors. This study aims to determine the use of social media as a means of political communication carried out by the Regional Leadership Council of the Indonesian Solidarity Party (DPW PSI) Jakarta. The research method uses a qualitative approach and case study methods. Data collection was carried out through online observations on Instagram, Twitter, and Facebook DPW PSI Jakarta social media accounts and interviews with the social media admins of DPW PSI Jakarta and the Chairman of DPW PSI Jakarta via Google Meet. The results of this study indicate that using social media is able to have an impact on the public by uploading content in the form of videos, photos and infographics as well as interesting captions, so that the public will respond to the content (feedback). In addition, social media is also very helpful in the process of political communication such as absorbing public aspirations, two-way communication and messages conveyed more clearly and effectively.
\end{abstract}

Keywords: social media, political communication, political party 


\section{PENDAHULUAN}

Komunikasi politik di media sosial berjejaring (khususnya Facebook, Twitter, Instagram, Youtube dll) dipermudah oleh keterhubungan citra visual, tekstual, dan verbal (Tosepu, 2018). Komunikasi politik merupakan cara menyampaikan pesan bercirikan politik yang bertujuan memengaruhi publik. Kehadiran media sosial tentunya dimanfaatkan sebagai media komunikasi oleh pemerintah, partai poltik, aktivis dan professional. Media sosial merupakan bagian penting bagi partai politik untuk memberikan informasi ke publik mengenai kegiatan politiknya. Media sosial dimanfaatkan oleh partai politik untuk kepentingan politik, karena media inilah yang memiliki kekuatan untuk itu memengaruhi berbagai audiens (Alam, 2019). Karena pengguna media sosial di Indonesia semakin banyak, penggunannya juga semakin meluas khususnya kepentingan politik pun ikut menghiasi. Dalam proses komunikasi politik di Indonesia, media baru menjadi media masa depan karena murah, akses cepat, mudah dan cepat secara langsung berinteraksi dengan komunikator (Wahid, 2016).

Media sosial mempunyai kekuatan dalam memengaruhi opini publik. Penggalangan dukungan melalui media sosial menjadi lebih cepat dalam menyampaikan pesan. Karena itu, media sosial telah menempatkan ruang demokrasi dalam babak baru dari perspektif komunikasi politik. Dengan demikian, media sosial sebagai sarana komunikasi memiliki peran membawa orang (penggunanya) untuk berpartisipasi secara aktif dengan memberi kontribusi dan feedback secara terbuka, baik untuk membagi informasi maupun memberi respon secara online dalam waktu yang cepat (Budiyono, 2017).

Media sosial sebagai media alternatif yang didukung oleh kekuatan teknologi komunikasi, sesungguhnya memiliki banyak manfaat dalam rangka meningkatkan pemahaman terhadap demokratisasi komunikasi menuju masyarakat informasi yang adil sejahtera (Susanto, 2017). Bagi partai politik, memanfaat media sosial dapat membangun komunikasi politik dengan kelompok atau organisasi politik dan pendukungnya. Menurut Matthew A. Baum dan Tim Groelling, pengguna media sosial berpotensi menjadi opinion leaders baru yang akan mendapatkan pengikutnya masing-masing (Hastuti, 2011). Karena itu, partai politik membutuhkan media sosial agar kadernya yang duduk sebagai anggota legislatif bisa memberikan informasi ke publik secara jujur dan transparan.

Fungsi dari legislatif secara khusus menangani pembentukan peraturan daerah, APBD dan pengawasan eksekutif harus mampu menyatukan pihak yang memiliki kepentingan tersebut. Oleh karena itu, media sosial menjadi penting untuk menyatukan berbagai kepentingan karena karakteristik media sosial sangat luas dan terkoneksi sangat cepat serta mampu mengaplikasikan media sosial dalam menjalankan aktifitasnya sebagai anggota legislatif Jakarta. Media sosial telah merubah sistem komunikasi yang tidak hanya satu arah, namun menjadi dua arah untuk mengoptimalkan komunikasi di berbagai sektor. Media sosial mendukung dalam mengelola isu di suatu organisasi seperti pengambilan keputusan, pemantauan, mengevaluasi dan menyerap aspirasi. Bahkan isu yang muncul dapat dikontrol dan diklarifikasi baik secara emosional maupun data. Komunikasi dua arah yang bersifat langsimg dan seketika pada social media dapat dimanfaatkan organisasi dalam memonitor opini dan reaksi publiknya secara lebih terbuka dan cepat (Pienrasmi, 2015). 
Berdasarkan pengamatan peneliti, media sosial DPW PSI Jakarta memiliki jumlah pengikut yang terbilang paling banyak di tingkat wilayah Provinsi DKI Jakarta dibandingkan dengan media sosial partai politik lainnya (Selasa, 7 Juli 2020 pukul 11:25 WIB). PSI Jakarta tercatat aktif menggunakan media sosial seperti Instagram, Twitter dan Facbook. Akun PSI DKI Jakarta memiliki pengikuti di akun Instagram @PSI_Jakarta 12.900 pengikut, akun Twitter@PSI_Jakarta 9.107 pengikut dan akun Facebook @PSI.Jakarta 12.556 pengikut (https://www.facebook.com/PSI.DKI/, https://twitter.com/PSI_Jakarta dan https://www.instagram.com/psi_jakarta/). PSI Jakarta sangat gencar menggunakan media sosialnya untuk menaikan popularitasnya kepada masyarakat bahwa ada partai baru bernama PSI untuk menampung aspirasi masyarakat DKI Jakarta (Moneter \& Susanto, 2020).

Akun media sosial PSI Jakarta digunakan untuk konten seputar kegiatan politik, mengkritis kebijakan Pemprov DKI, mengawasi anggaran DKI Jakarta hingga sosialisasi menemui warga Jakarta. penggunaan media sosial telah memberikan banyak pengaruh positif terhadap komunikasi politik dan demokrasi di Indonesia karena dapat menurunkan jumlah rintangan komunikasi dalam ruang dan waktu (Bhakti, 2020). Hal ini memperkuat komunikasi poltik dalam praktik politik modern yang mana media sosial menjadi media alternatif. Oleh karena itu, hadrinya media sosial merupakan peluang bagi anggota legislatif dari DPW PSI Jakarta merepresentasikan rakyat. DPRD dapat mendekatkan diri dengan rakyat melalui media sosial, baik untuk menyosialisasikan kegiatan, menyerap informasi dan aspirasi, serta berkomunikasi langsung untuk mengetahui keinginan rakyat, sehingga program-program sebagaimana fungsinya (Hikmat, 2018). Sehingga informasi ke masyarakat lebih cepat dan mengetahui kinerja wakil rakyatnya. Oleh karena itu, media sosial menjadi penting untuk komunikasi politik ke masyarakat.

Penelitian dengan tema sejenis penelitian ini dilakukan oleh Azeem \& Toni pada tahun 2018 yang berjudul "Strategi Humas Kementerian Koperasi dan Usaha Kecil dan Menengah Dalam Pengelolaan Jejaring Sosial". Kementerian Koprasi dan UKM RI menggunakan media sosial sebagai komunikasi dua arah. Hasil penelitian ini menunjukan pengelolaan media sosial di Kementerian Koperasi dan UKM RI yang baik seperti pengelolaan tanda informasi, umpan balik, pengembangan fokus dan juga pemanfaatan bahasa.

Selanjutnya, penelitian Maulana \& Syam (2019) dengan judul "Pemanfaatan Media Sosial Instagram Sebagai Sarana Penggalangan Dana (Fundraising) Oleh Lembaga Aksi Cepat Tanggap Aceh". Media sosial tidak hanya digunakan sebagai media promosi tetapi juga bisa memanfaatkan untuk penggalangan dana. Oleh karena itu, terdapat kaitannya dengan komunikasi, yakni proses memberikan pesan ke orang lain merubah secara kognisi, afektif dan konatif. Hasilnya dengan memanfaatkan media sosial Instagram oleh ACT Aceh, masyarakat terpengaruh untuk ikut menyumbang. Selain itu, konten media sosial ACT Aceh dibuat semenarik mungkin, sehingga muncul atensi masyarakat dari berbagai elemen.

Kedua penelitian tersebut menjadi refrensi kajian literatur dalam penelitian ini. Perbedaannya terletak pada penggunaan media sosial yang fokus mengelola dan menyebarkan infromasi. Sedangkan penelitian ini lebih fokus pada penggunaan media sosial yang tidak sekedar mengelola maupun menyebarkan informasi tetapi menjadi wadah aspirasi bagi partai politik maupun legislatif. 
Penelitian ini sangat penting dilaksanakan dalam ranah akademis dan praktis mengenai cara penggunaan media sosial sebagai komunikasi politik. Penelitian ini juga bisa dijadikan bahan refrensi untuk dipraktikkan secara nyata. Atas alasan tersebut, peneliti merumuskan penelitian, yakni bagaimana penggunaan media sosial sebagai alat komunikasi politik yang dilakukan DPW PSI Jakarta?

\section{METODE PENELITIAN}

Penelitian ini adalah penelitian kualitatif dengan metode studi kasus. Metode studi kasus (case study) biasa digunakan untuk mendeskripsikan dan menjelaskan sebuah kasus aktual yang terjadi pada waktu tertentu (Wahid, 2016).

Pengumpulan data penelitian ini yaitu wawancara, observasi, studi kepustakaan dan penelusuran data online. Peneliti melakukan wawancara mengambil sampling informan, yaitu Michael Victor Sianipar (Ketua DPW PSI Jakarta) dan Winahya Adi (admin media sosial DPW PSI Jakarta) pada 16 dan 22 Oktober 2020 melalui ZOOM. Peneliti juga melakukan observasi seperti mengamati langsung terhadap unggahan konten media sosial DPW PSI Jakarta berupa video dan foto.

Analisis data dalam penelitian ini, yaitu reduksi, penyajian data dan kesimpulan. Temuan terdapat berupa deskripsi atau gambaran suatu objek yang sebelumnya masih remang-remang atau gelap sehingga setelah diteliti menjadi jelas, dapat berupa kausal atau interaktif, hipotesis atau teori (Sugiyono, 2011).

Tabel 1 Media Sosial PSI Jakarta

\begin{tabular}{|l|l|l|}
\hline Instagram & 13.126 followers & 180 following \\
\hline Twitter & 9.465 followers & 251 following \\
\hline Facebook & 12.680 followers & 12.460 like \\
\hline
\end{tabular}

Sumber: Sumber Data (2020)

\section{HASIL DAN PEMBAHASAN}

Dalam menganalisis penelitian mengenai penggunaan media sosial, penyampaian pesan sesuai dengan Teori Kekayaan Media atau Media Richness Theory. Teori ini memiliki empat aspek, yaitu bagaimana penggunaan media sosial sebagai alat komunikasi politik yang dilakukan DPW PSI dapat menangani tanda informasi, feedback, pengembangan fokus dan pemanfaatan bahasa. Media yang dapat mengatasi perbedaan kerangka acuan referensi dengan efisien dan mengklarifikasi isu-isu yang ambigu dianggap lebih sempurna dibandingkan media komunikasi yang membutuhkan waktu lebih lama untuk menyampaikan pemahaman (Daft \& Lengel, 1986).

Peneliti menemukan bahwa media sosial sangat efektif dalam komunikasi politik. Media sosial yang digunakan PSI Jakarta seperti Instagram, Facebook dan Twitter tidak sebatas menyebarkan informasi namun media sosial tersebut sudah memiliki berbagai fungsi. Oleh karena itu, media sosial sangat efektif sebagai wadah untuk komunikasi politik wakil rakyat.

\section{Penggunaan Media Sosial sebagai Komunikasi Politik dalam Tanda Informasi}

Dalam proses penggunaan media sosial yang dilakukan oleh DPW PSI Jakarta, perlu adanya koordinasi antar pengurus partai dari tingkat Dewan Pimpinan Pusat (DPP) 
hingga Dewan Pimpinan Ranting (DPRt). Hal ini agar informasi yang disampaikan lebih fokus dan terarah. Dalam praktiknya, admin DPW PSI Jakarta bersama dengan pihak yang dikoordinasikan harus menyamakan pandangan terlebih dahulu seperti apa konten yang akan diposting.

Setelah menyamakan persepsi dan mendapatkan arahan, selanjutnya menentukan segementasi publik. Publik di sini yang dimaksud adalah sasaran yang hendak dituju. Sejak berdirinya PSI, sasarannya adalah anak muda. Oleh karena itu, konten yang dibuat DPW PSI Jakarta berkaitan dengan anak-anak muda.

Jadi intinya dari DPP memberikan arahan, DPP sudah ada point-point, sudah ada yang harus diperjuangkan sampai DPRT, DPC sampai DPW. Jadi yang dari bawah itu, pertama sesuai kampanyenya partai anak muda dulu, makanya kenapa kalau dilihat anggota-anggota, jubir-jubir kebanyakan anak muda. Dari situ kita ikutin kalau mau jadi partai muda harus tahu dulu anak muda itu seperti apa. Salah satunya pengguna media sosial ini. Kita lebih gunakan media sosial ini semacam senjata paling ampuh, tool yang ideal yang membaur anak muda. Apalagi Jakarta pengguna internet terbesar di Indonesia (Wawancara Winahya Adi sebagai admin media sosial DPW PSI Jakarta pada 16 Oktober 2020).

Sementara, Michael Victor Sianipar mengatakan media sosial sebagai komunikasi politik digunakan untuk saluran pengenalan PSI kepada anak muda. Ia menambahkan bahwa anak muda memiliki populasi sangat besar. Untuk mendekatkan anak muda, DPW PSI Jakarta melakukan berbagai cara, salah satunya penggunaan teknologi seperti media sosial. Sebagai partai baru, PSI memiliki perbedaan dengan partai politik lainya, lebih menonjolkan partai kekininan. Hal ini bagian dari strategi PSI dalam mendekatkan anak muda.

Jadi pangsa besar itu anak muda dan usia produktif. Di PSI kita menargetkan anak muda dan pengurus kita anak muda. Kalau sekarang lebih fleksibel juga. Misal di DKI Jakarta pengurus PSI masih muda. Jadi kita nargetkan anak muda karena kita anak muda. Karena anak muda pangsa suaranya besar. (Wawancara Michael Victor Sianipar sebagai Ketua DPW PSI Jakarta pada 18 Oktober 2020).

Dalam menggunakan berbagai macam media sosial pada periode 2018-2019, DPW PSI Jakarta memiliki target politik, yaitu menaikan followers di setiap media sosialnya, memperkenalkan calon anggota legislatif dan menaikan elektabilitas setiap calon anggota legislatif. Setelah para calon anggota legislatif ini resmi menjadi anggota DPRD DKI Jakarta, admin DPW PSI Jakarta merubah strategi dalam komunikasi politiknya. Bentuk tanda informasi yang dilakukan oleh media sosial DPW PSI Jakarta saat memposting foto dan video terkait dengan kegiatan anggota dewan, kebijakan pemprov, isu yang sedang hangat di Jakarta dan lain-lain.

Target politiknya jelas pertama ketika Pileg 2018-2019, targetnya itu untuk menaikan followers, memperkenalkan anggota legislatif-nya. Selanjutnya elektabilitas dan Caleg itu sendiri. Dan latar belakangnya macam-macam, ada yang tidak aktif media sosial, ada yang sangat influence, ada yang kaku dan biasa-biasa aja aktif dan pasif juga. Target poltik, gimana caranya hidupin media sosial PSI Jakarta \& hidupin akun Caleg-nya di Jakarta ada beberapa jumlahnya dan yang lolos 8 orang. Tergetnya melenggangkan anggota PSI di DPRD Jakarta untuk pertama kalinya. Tergetnya menaikan popularitas \& 
elektabilitas (Wawancara Winahya Adi sebagai admin media sosial DPW PSI Jakarta pada 16 Oktober 2020).

Penggunaan media sosial dalam hal aktivitas komunikasi akan berbeda. Artinya, media sosial memiliki kareakteristik berbeda-beda, begitu juga audiens berbeda. DPW PSI Jakarta melakukan penanganan tanda informasi seperti di kolom komentar atau menyukai sangat responsif. Namun setiap tanda informasi tersebut tergantung pada isi komentar dari publik (Azeem \& Toni, 2018).

Kalau berbau SARA, hoaks atau ini akun ternak follower-nya enggak ada atau cyber ARMY, kita tidak tanggapi. Kalau memang akun verifed, dia punya akun valid beckground-nya kita tanggapi (Wawancara Winahya Adi sebagai admin media sosial DPW PSI Jakarta pada 16 Oktober 2020).

Adanya penggunaan tanda informasi dari publik melalui media sosial menandakan bahwa DPW PSI Jakarta memilah-milah informasi mana yang perlu ditanggapi, mana yang tidak ditanggapi. Sebab, di kolom komentar media sosial DPW PSI Jakarta banyak ditemukan informasi berkaitan dengan hoaks, hate speech hingga pertengkaran antar-netizen.

\section{Penggunaan Media Sosial sebagai Komunikasi Politik dalam Feedback Pesan.}

Media sosial yang digunakan oleh DPW PSI Jakarta baik itu Instagram, Twitter dan Facebook mampu mengirimkan pesan secara serempak dan cepat. Sehingga, siapa pun bisa mengakses konten yang diposting oleh DPW PSI Jakarta.

DPW PSI Jakarta berusaha menanggapi respons yang baik atas semua feedback yang diterima dari publik. Admin DPW PSI Jakarta menjadi fasilator antara Fraksi DPRD PSI Jakarta dengan masyarakat Jakarta dengan memberikan feedback yang komunikatif. Ada dua hal yang langsung diberi feedback.

Pengaduan PSI Jakarta secara terbuka di situ masyarakat bisa mengadu lewat DM Instagram atau komen. Kalau itu bisa langsung. Kedua informasi yang sedang berkembang. Contohnya, rapat Banggar (Badang Anggaran) lagi bahas permasalah anggaran Damkar (pemadan kebarakan). Kita keluarin kontennya memang anggaran Damkar tahun lalu dan tahun sekarang (Wawancara Winahya Adi sebagai admin media sosial DPW PSI Jakarta pada 16 Oktober 2020).

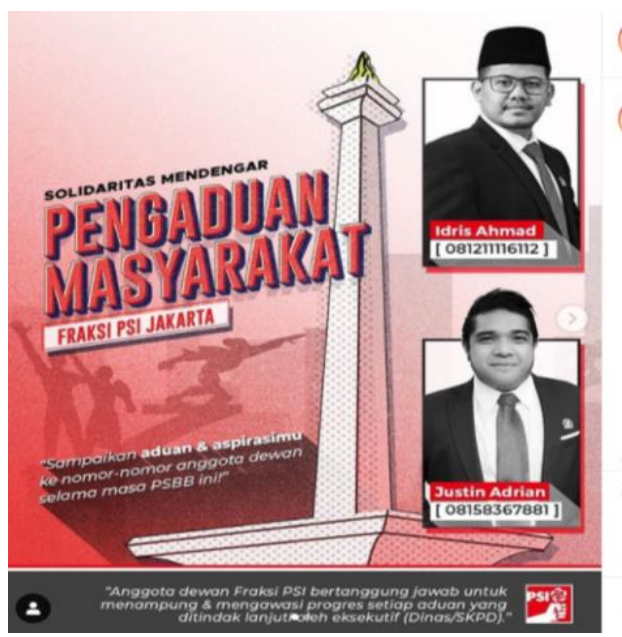

Sumber: objek penelitian, 2020

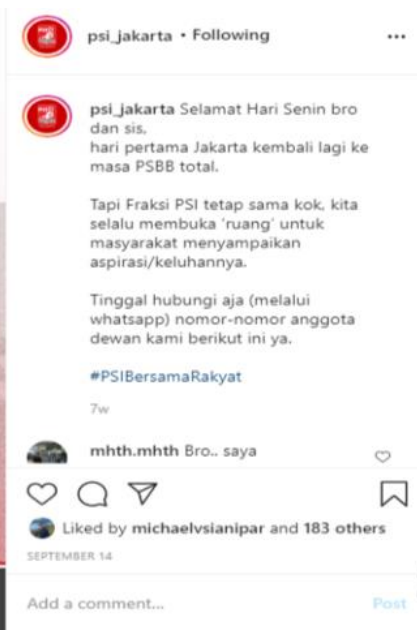

ద 
Gambar 1. Konten Pengaduan Masyarakat

Konten di atas harus dipertahankan dan selalu ada minimal setiap Minggu. Hal ini untuk keberlangsungan feedback yang akan direspons oleh DPW PSI Jakarta. Penggunaan media sosial oleh DPW PSI Jakarta sangat berguna dan bermanfaat bagi kepentingan masyarakat umum.

\section{Penggunaan Media Sosial sebagai Komunikasi Politik dalam Pengembangan Fokus.}

Sebagai salah satu partai politik baru yang masuk dalam DPRD Provinsi DKI Jakarta, DPW PSI Jakarta merupakan partai yang menjalankan tugasnya dalam pengawasan APBD dan mengawasi jalannya pemerintahan pemprov DKI Jakarta, tentu sangat penting memperkenalkan partainya kepada publik. Hal ini bertujuan untuk pengetahuan dan edukasi politik yang dapat memberi fasilitas berbagai kegiatan baik di DPW maupun di Fraksi DPRD PSI Jakarta.

Salah satu cara meningkatkan hubungan personal, yakni dengan cara penggunaan media sosial. Karena media memiliki kemampuan untuk memberi efek pengetahuan (kognisi) bahkan emosional dari pihak yang berkomunikasi.
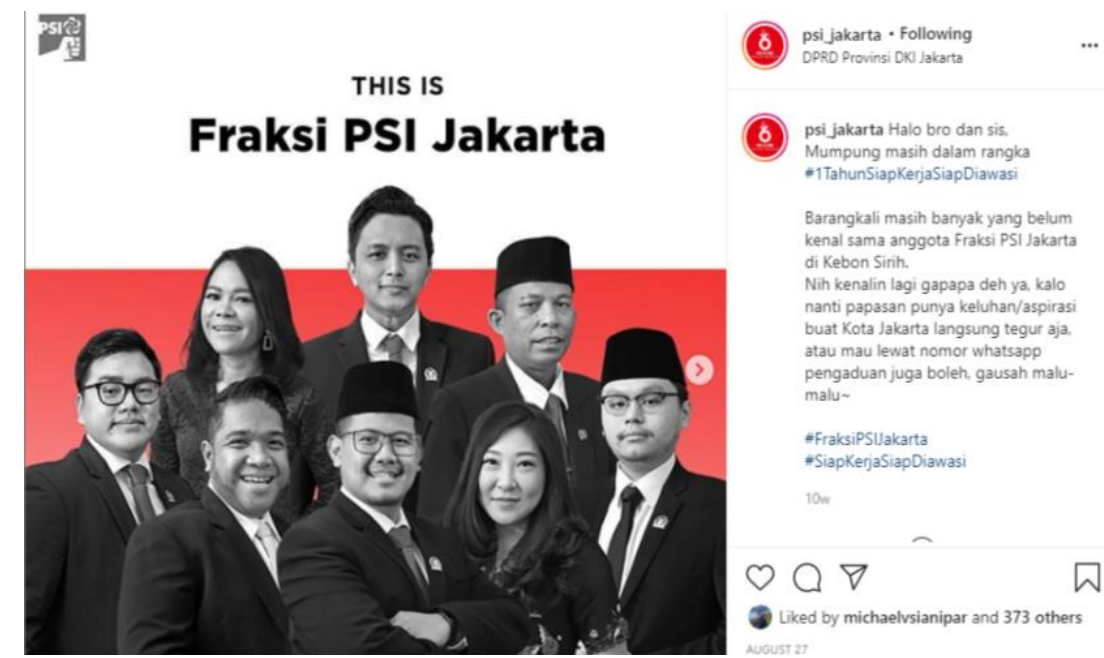

Sumber: objek penelitian, 2020

\section{Gambar 2. Konten Pengenalan Fraksi DPRD PSI Jakarta}

Penggunanan media sosial yang dilakukan DPW PSI Jakarta mulai dari Instagram, Twitter, dan Facebook dijadikan media untuk meningkatkan hubungan dengan publik. Media sosial merupakan alat untuk menyebarluaskan informasi dari DPW PSI Jakarta bisa dijadikan wadah untuk memperkenalkan partai politik kepada publik. Sehingga, konten yang dibuat lebih ringan dan menarik.

Aku sebagai yang handle, aku compare dulu konten-konten seperti apa memang jarang banget bersentuhan anak-anak muda dari segi desain, publikasi dan interkasi itu membosankan. Ketika aku tidak dapat di daerah dan pusat. Aku compare-nya ke luar negeri misalnya partai Republik atau Demokrat di AS itu beda jauh cara mereka memakai lintas umur dari segi konten dan publikasi sangat menarik kita aplikasikan ke sini. Apple to apple jadi keluar kontenya seperti apa oh style-nya seperti ini baru kita sisipin. Intinya yang menting kemasan dulu karena secara isi aja berat, kalau kemasannya enggak menarik 
ngliat gimana lebih mendalam dan membaca ikutin politik makanya setelah itu bikin politik itu ringan selanjutnya ada hal-hal yang viral kita coba nebeng viralnya itu. (Wawancara Winahya Adi sebagai admin media sosial DPW PSI Jakarta pada 16 Oktober 2020).

Proses pengembangan partai oleh DPW PSI Jakarta melalui media sosialnya dapat dilihat dari berbagai hal, sebagai berikut:

1. Dari segi foto: Foto di media sosial DPW PSI Jakarta lebih interaktif dan menarik. Sehingga, publik pun dapat memahami pesan yang disampaikan oleh DPW PSI Jakarta.

2. Dari segi video: Video di media sosial DPW PSI Jakarta disisipkan fakta dan data berupa infografis atau ilustrasi mengenai kegiatan para anggota DPRD. Misalkan, rapat paripurna, kegiatan reses, dan lain-lain. Kegiatan tersebut dibuat menjadi cerita yang menarik.

3. Dari segi caption: Untuk menarik perhatian publik khususnya anak muda, caption yang digunakan DPW PSI Jakarta menggunakan bahasa non-formal dan kekinian. Sebetulnya setiap konten itu dua hal diterapkan edukatif dan entertaiment. Selain informasi tapi kita berikan entertaiment biar enak dilihat mata. Sebisa kita beri konten apa adanya tidak ada pandangan. Misalnya ada infografis, misalnya Pansus itu apa sih? Tujuanyan apa sih Pansus? Kita buat infografisnya. Lalu ini kan pandemi kita bikin infografisnya (Wawancara Winahya Adi sebagai admin media sosial DPW PSI Jakarta pada 16 Oktober 2020).

\section{Penggunaan Media Sosial sebagai Komunikasi Politik dalam Memanfaatkan Bahasa}

Penggunaan bahasa merupakan bentuk komunikasi yang dapat memahami isi pesan antar komunikator dengan komunikan. Artinya, penggunaan bahasa yang baik, benar dan menciptakan situasi interaktif. Begitu juga dalam menggunakan media sosial sudah seharusnya bahasa yang digunakan jelas dan dimengerti bagi pembaca atau penonton. Misalkan unggahan pengaduan masyarakat mengenai PSBB total di Instagram dan evaluasi Fraksi PSI di DPRD DKI Jakarta atas tiga tahun pemerintahan Gubernur Anies Baswedan di Facebook:

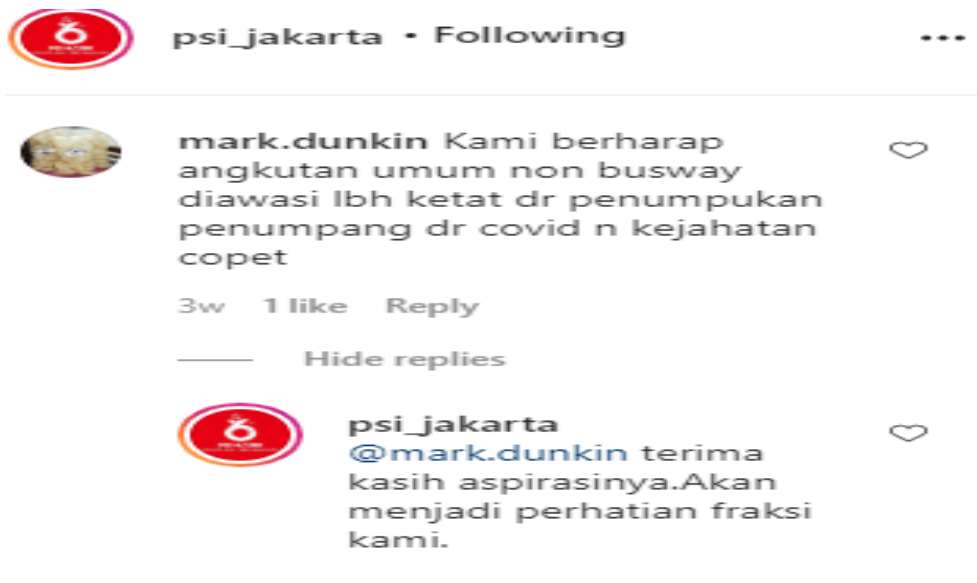

Sumber: Sumber: objek penelitian, 2020

Gambar 3. Tanggapan di Media Sosial Instagram 
Pada gambar di atas menjelaskan informasi bahwa konten yang diunggah media sosial DPW PSI Jakarta telah melakukan komunikasi dan merespons dari berbagai tanggapan publik. Admin media sosial DPW PSI Jakarta memberikan tanggapan dengan bahasa yang tidak hanya formal tetapi bisa dipahami public khususnya anak muda.

Yang jelas bahasanya bisa dipahami dan bisa dicerna sekali oleh anak muda banget. Secara kita pakai bro dan sis pakai kalimat-kalimat sesuai dengan konten, secara level, high level, semi formal dan formal, lebih ringan, lebih sehari-hari saja anak muda bicarakan (Wawancara Winahya Adi sebagai admin media sosial DPW PSI Jakarta pada 16 Oktober 2020).

Meski demikian, admin DPW PSI Jakarta mengaku membuat konten yang berisikan bahasa politik perlu melakukan koordinasi dan berkomunikasi langsung dengan tenaga ahli Fraksi DPRD PSI Jakarta. Hal ini agar konten yang dibuat admin DPW PSI Jakarta sesuai arahan dari perwakilan DPRD PSI Jakarta.

Tampilan lebih menarik dulu kalau enggak menarik enggak ada yang tertarik dari segi packaging-nya konten ini lebih menarik dulu untuk mudah dipaham. Kita berfikir subtansi politik itu berat. Kita coba strateginya macem-macem, kita bikin kuis semacam interaktif action sudah banyak banget media sosial secara tidak langsung ada subtansi masyarakat enggak langsung masyarakt lebih ringan, ada infografis lebih simpel dan dapat pointnya lebih dapat sebisa mungkin konten sederhana \& tidak bertele-tele bahasa lebih mengerti. Kalau bahasa politik kita jelaskan dulu di legislatif ada bahasa asing. Sebisa mungkin pela-pelan ngasih konten poltik. (Wawancara Winahya Adi sebagai admin media sosial DPW PSI Jakarta pada 16 Oktober 2020).

DPW PSI Jakarta sudah melakukan komunikasi dua arah dengan baik dan bahasa yang digunakan untuk tanggapan, bahasa yang mudah dipahami publik. Diharapkan kedepannya, DPW PSI Jakarta lebih komunikatif dalam hal menyampaikan informasi dan memberikan feedback dari berbagai pertanyaan publik.

Dalam penelitian Anshari (2013), partai politik menggunakan media sosial hanya media untuk mendapatkan popularitas dan dukungan dari masyarakat. Bahkan, belum menyasar pada interaksi dan menyerap aspirasi. Namun, DPW PSI Jakarta menggunakan media sosialnya sebagai komunikasi politik kepada publik sudah baik dan benar. Terbukti adanya feedback dan konten aspiratif. Hal ini ditemukan media sosial Instagram, Twitter dan Facebook di DPW PSI Jakarta.

Penggunaan media sosial sebagai komunikasi politik mampu mendukung aktifitas politik DPW PSI Jakarta, dikenal masyarakat luas dan mendapatkan atensi yang baik bagi pengguna media sosial. Penanganan tanda informasi dalam penggunanan media sosial sebagai komunikasi politik yang dilakukan DPW PSI Jakarta. Dalam penanganannya, admin DPW PSI Jakarta sangat merespons dan sangat baik mengelola tanda informasi dari media sosialnya. Misalnya, ada tanda informasi seperti di kolom komentar atau menyukai dari publik, maka admin DPW PSI Jakarta akan merespons atau membalas. Namun setiap tanda informasi tersebut tergantung pada isi komentar. Sebab, di kolom komentar media sosial DPW PSI Jakarta terdapat informasi berkaitan dengan informasi hoaks, hate speech hingga pertengkaran antar-netizen.

Media sosial yang digunakan oleh DPW PSI Jakarta dalam mengelola feedback pesan yang diterima dari publik sangat responsif. Admin DPW PSI Jakarta menjadi 
perantara Fraksi DPRD PSI Jakarta dengan masyarakat. Misalnya, ada pengaduan dari publik yang mengirimkan pesan ke media sosial, DPW PSI Jakarta selaku fasilator akan menampung pengaduan tersebut dan langsung disampaikan ke Fraksi DPRD PSI Jakarta. Hal ini dilakukan agar aspirasi dari publik bisa tersampaikan dengan baik. DPW PSI Jakarta merupakan partai baru yang pertama kali kadernya masuk ke DPRD Jakarta, tentunya media sosial digunakan meningkatkan popularitas. Hal tersebut bentuk wujud keberadaan DPW PSI Jakarta bahwa partai merupakan perpanjangan tangan dari masyarakat. Sehingga, pengembangan fokus dari DPW PSI Jakarta, yakni dikenal sebagai partai baru dan anak muda. Terlihat dari media sosialnya mengunggah konten, foto yang interaktif dan menarik, video disisipkan fakta dan data berupa infografis atau ilustrasi dan caption digunakan bahasa nonformal dan kekinian.

Penggunaan bahasa yang digunakan DPW PSI Jakarta sudah jelas dan mudah dimengerti bagi pembaca atau penonton serta mengikuti perkembangan anak muda sekarang. Karena penggunaan bahasa merupakan capaian admin media sosial PSI Jakarta dalam menyampaikan pesan ke khalayak luas. Oleh karena itu, pesan yang diberikan dengan baik kepada khalayak.

\section{SIMPULAN}

Penggunaan media sosial seperti Instagram, Twitter dan Facebook yang dilakukan oleh DPW PSI Jakarta mampu memberikan dampak pengaruh tersendiri dalam komunikasi politik secara virtual. Terutama dengan mengunggah video dan foto serta caption menarik bisa mendapatkan respons. Karena itu, media sosial menjadi hal sangat dibutuhkan bagi partai politik.

Media sosial sangat membantu dalam menyerap aspirasi dan menghubungkan antara anggota DPRD DKI Jakarta dengan masyarakat. Aspirasi tersebut bisa dilakukan melalui kolom komentar atau direct message di media sosial. Karena media sosial sebagai salah satu alat komunikasi dua arah (feedback) dan bahasa yang digunakan mudah dimengerti masyarakat khususnya anak muda. Namun, DPW PSI Jakarta tidak semua merespons tanggapan dari masyarakat karena informasi diterima juga ada yang bersifat negatif seperti SARA atau hate speech.

Kendati demikian, penelitian ini dapat dikembangkan lebih lanjut menggunakan metode netnografi untuk melihat fenomena sosial di ruang siber. Selain itu, bisa dijadikan wadah pelatihan untuk para admin media sosial, sehingga penggunaan media sosial tidak sekedar mengunggah konten semata tapi juga bisa menjadi media menyerap aspirasi dan ditindaklanjuti secara offline.

\section{UCAPAN TERIMA KASIH}

Penulis menyampaikan terima kasih banyak kepada seluruh tim redaksi Jurnal Avant Garde dan para reviewer atas masukan yang telah diberikan pada artikel ini, sehingga artikel ini bisa dimuat. Semoga artikel ini dapat bermanfaat bagi pembaca dan mempertambah refrensi ilmiah khususnya penelitian komunikasi politik dan media sosial. 


\section{DAFTAR PUSTAKA}

Alam, Sukma. 2019. Strategy of Political Party Campaign on Social Media (Case Study of Partai Soldaritas Indonesia in Criticizing The Indonesian parliament through YouTube). Vol 2 No 1. Desember: 494-498

Anshari, Faridhian. 2013. Komunikasi Politik di Era Media Sosial. Jurnal Komunikasi. Volume 8. Nomor 1. Oktober: 91-101

Azeem, Mohammad Ribhul \& Toni, Ahmad. 2018. Strategi Humas Kementerian Koperasi dan Usaha Kecil dan Menengah Dalam Pengelolaan Jejaring Sosial. Volume 10. Nomor 2. Desember: $115-130$

Bhakti, Sufri Eka. 2020. Ruang Publik dan Media Sosial: Partisipasi Politik Mahasiswa Indonesia. Jurnal kajian media. Volume 4. Nomor 1. Juni: 1-10

Daft, RL. \& Lengel, R.H. 1986. Organizational information requirements, media richness and structural design, Management Science. Volume 32. Nomor 5. Mei: 554-71.

Budiyono. 2016. Media Sosial dan Komunikasi Politik: Media Sosial sebagai Komunikasi Politik Menjelang Pilkada DKI Jakarta 2017. Jurnal Komunikasi. Volume 11. Nomor 1. Oktober: 47-62

Hastuti, Sri. 2011. New Media: Teori dan Aplikasi. Surakarta: Lindu Pustaka.

Hikmat, Mahi M. 2018. Strategi Pemanfaatan Media Sosial untuk Meningkatkan Citra Positif DPRD dalam Persepsi Rakyat Daerah. Jurnal Common. Volume 2. Nomor 1. Juni: $35-56$

Moneter, Bella Adha Hendriana \& Susanto, Eko Harry. 2020. Strategi Komunikasi Politik Partai Baru (Studi Kasus Perolehan Suara Partai Solidaritas Indonesia di DPRD DKI Jakarta Pada Pemilu 2019). Volume 4. Nomor 1. Maret: 43-49.

Maulana, Ghaffar \& Syam, Hamdani M. 2019. Pemanfaatan Media Sosial Instagram Sebagai Sarana Penggalangan Dana (fundraising) oleh Lembaga Aksi Cepat Tanggap Aceh. Jurnal Ilmiah Mahasiswa FISIP Unsyiah. Volume 4. Nomor 3. Agustus.

Pienrasmi, Hanindyalaila. 2015. Pemanfaatan Social Media oleh Praktisi Public Relations. Jurnal Komunikasi. Volume 9. Nomor 2. April: 199-210.

Tosepu, Yusrin Ahmad. 2018. Media Baru Dalam Komunikasi Politik (Komunikasi Politik di Dunia Virtual). Surabaya. CV Jakad.

Susanto, Eko Harry. 2017. Media Sosial Sebagai Pendukung Jaringan Komunikasi Politik. Jurnal ASPIKOM. Volume 3. Nomor 3. Juli: 379-398.

Sugiyono. 2011. Metode Penelitian Kuantitatif Kualitatif R\&D. Bandung. Alfabeta.

Wahid, Umaimah. 2016. Komunikasi Politik Teori, Konsep, dan Aplikasi Pada Era Media Baru. Bandung. PT Remaja Rosdakarya 